\title{
MEMOIR
}

\section{ROBERT KNIGHT LOCHHEAD}

Bob Lochhead in his mid-eighties was outstandingly well informed and vigorous in expression; his vitality and continuing interest in the profession made him a bridge to a previous generation of actuaries. He loved conversation and his remarkable memory enabled him to draw on his long experience and to provide parallels with past events which frequently helped to analyse a problem which was being discussed with him.

Service to the Institute was a major part of his life and he was actively involved throughout his career. Students in the 1920 s had to prepare for examinations without textbooks in many subjects and personal relationships with their tutors were all important. Many years later when he and Sir George Maddex were guests of the Actuaries' Club to mark their 85th birthdays many members spoke with affection of the lucid and helpful kindness that they had received as students, and in reply modest reference was made to the number of future presidents who had passed through their hands. A later generation of students regarded Lochhead on Valuation and Surplus, published in 1932, as a classic textbook, although the author always maintained that it was more a guide to reading amongst the papers and discussions published in the Journal.

He was born in 1894, the son of a Scottish bank manager who had moved to London, and was educated at St Paul's School, Kensington. Almost the whole of his career was with the Commercial Union which he joined shortly before the First World War after a brief period with the Clerical Medical and General. He volunteered for active service in September 1914 and in November that year he left for France where he served almost continuously for 5 years. In April 1915 he was commissioned into the Argyll \& Sutherland Highlanders and attained the rank of captain.

After his return to actuarial studies in September 1919 he made rapid progress for those days, even taking into account the half-yearly examinations which were introduced for the benefit of those whose careers had been interrupted. Fellowship of the Institute was attained in 1923 and the 1980 Year Book showed him as then tenth in seniority.

He served for 18 years on Council and held the offices of Chairman of the Students' Society, Chairman of the Examination Board, Honorary Secretary, Vice-President and Chairman of the Appointments Board.

In his office he formed an embryonic research and development section within the Actuarial Department in the early 1930s, and it was his success in assisting the Secretarial Department with problems of yield calculations on fixed interest investments which led to his appointment as Secretary in 1936. It can be regarded as practically certain that if this had not happened he would have become Actuary of Commercial Union a few years later. His responsibilities increased greatly over the succeeding years, but it is remarkable to note that his title remained unchanged until his retirement in 1959 when he was appointed to the Board.

Bob Lochhead had presence and a great zest for life, always applying himself wholeheartedly to the job in hand. He had a brisk, almost regimental, appearance and a friendly grin was always close to the surface. He spoke lucidly, was quick on the up-take and had the ability to raise the standard of discussion in any meeting that he joined. He had high standards for himself and his staff, with a modest attitude concerning his own salary which was extended to the remuneration of his subordinates. A sincere declaration of how fortunate it was to remain below the surtax level was on one occasion received with some disappointment, although without impairing the affection that those concerned felt for him.

In the investment world he was recognized as a leader and his chairmanship of the Investment Protection Committec of the British Insurance Association ran for the record period of 7 years, during which time there were many problems which his skill and friendly acumen helped to solve. He also served on the Council of Foreign Bondholders for many years during which time he tried, often frustratedly, to secure fair treatment for the unfortunate bondholders. 
His experience in financial matters, service in the First World War and his charitable instincts combined in his outstanding service to the Royal Patriotic Fund of which he was a member of the Executive Committee for 25 years and Chairman of the Finance Committee for 17 years.

Shortly after retirement in 1959 he was one of the inspectors appointed by the Board of Trade to enquire into the affairs of the Pilot Insurance Company, and he also took on several directorships. It is typical that the directorship that he retained until his death was an honorary position as a member of the Council of the Royal National Pension Fund for Nurses; indeed he had to pay two guincas a year for the privilege.

A strong commitment to family life was characteristic and he always impressed his colleagues with the priority which he gave to family activities. His wife, Mary, died in 1966 and he is survived by two married daughters.

The same enthusiasm and application he displayed in his work was apparent in his social life and particularly golf at which he was exceptionally keen. His truly phenomenal memory for faces, names and events from the distant past was never more evident than at dinners of the Insurance Golfing Society. He regularly attended the Actuaries' and Gallio clubs right up to his death and had served as chairman of both of them. He was the senior nember of the Actuaries Club having been elected in 1938 and he established a record number of attendances at their meetings.

Bob Loch head was a most likeable man and a leader who earned the personal affection and loyalty of his staff and the respect of his colleagues. He was a good speaker, excellent in committec and supcrb as a negotiator. He retained his interests, vitality and memory into old age and was fortunate that he was ill for only a few days before his death on 17 November 1980, aged 86.

At his funeral the chapel was full with many standing to hear a remarkable tribute to his full and varied life by his Church of Scotland minister.

J. H. WeBB 